激るむ消来のいれ族 なとなえて機てて同刊と昭 極考いない能、心族行そ和

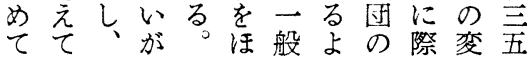
大以も、私とにう研し化年 きるっ戦のん同に究、旦 なよと後よと族私にこが本 変う別派う㟕団に今の之社 化にののな失㤎は日問り会 新若戦し大思的題上学 し見かい前てきわなの汗会 たえら人派いなれ意意ら第 こる出々のる意る。義義机亥

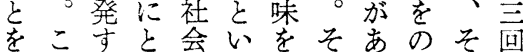
私のるっ学う持れるべの大 達こ方て徒現たはかて討会 にと染はに実な端とお議の 示は農そとにい的いきがシ し戦村れっ多ばにうた行ン て争をはてくかいこいなポ

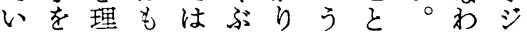
る境解は同っでと㔔れウ

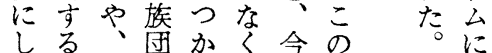
てこ何へる、今閣今お 農々等のこも農題そい 村吕の関々は村にのて 出出魅心妿やに含 内六 急来力はらそおま容同

いるそ本時し 戦もじが たこの家期て私にあめ急し りと本とで農を突りてにか 、家采あ村は久、心減し あ発が蒙っをじし逆る退よ る見雇とた歩め、䋦ししく はた夫主少廻喜後れ明の劣 変こ婦従くっ多—が治でて 化とを的とて野斉強・は見 しが含関もい清に化大なる

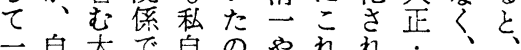
般盼き密身は故焦昭所戦 化のな接に昭及崩変和に後 し 郷家なつ和川れ形のょの た里族互い五宏てさ時っ急 心構助て年な来れ代て激 ろ其成関い頃をたた的はな 心他を係う吕加と場経江変 ろに持をなら同心合過六化 のおつ持ら第族うをる時に 社いてつ、四こあ間代よ 会てい家東次の方法加 現断る連北大定でた次らて 象片耕合地戦義あ方第守同 の的作を方終うる、にで族 源に地形に焉けと第崩に団 流残主成おまに思示饥崩の をっでしいで苦う次たれ機

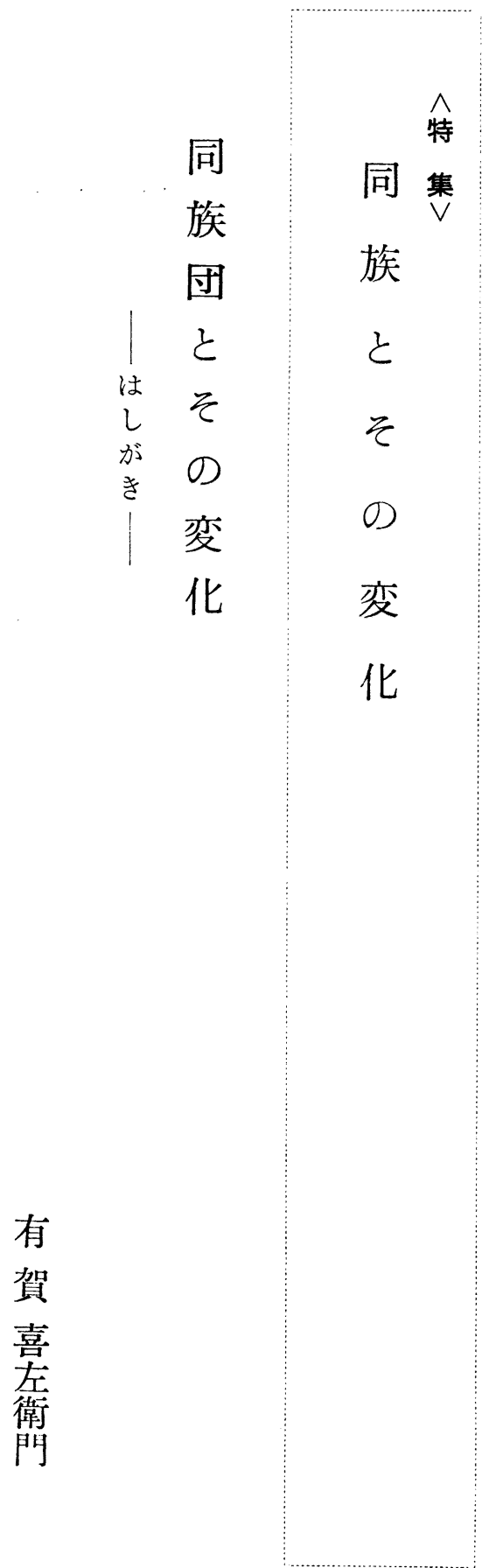


れたの見族族に即必半っでな はのに省祭歴的私やびま

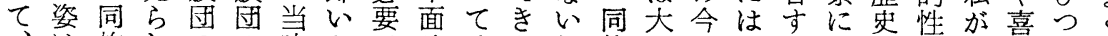
は族れのの時たでそそなし族い日やる同研格同多け説 種、団る研基の。あれのい目に的む所族究を族野て明 々特の所究本研そっの原。本は望関をで団に知団に明し の定現でに的究した変初こ社そま心得は偏加らの教かて 形の実あ限性をては化的の会のしのな重なな源えにく 態同のるら格兒そずし形よの当い中かるのり流らしれ

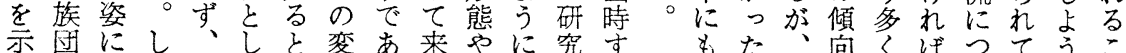

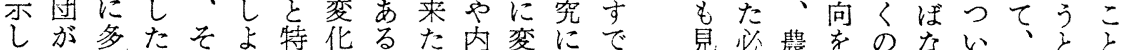

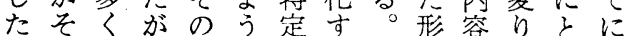
場の影っ他とのる私態をつっ大 合地響ての向過自队復つてい 召域さ研研る族程身内原亦重に 多社れ究究傾団のに容する要変 汃会た者に向の研関をる現なり っよはつが変究すをこ象課つ た特う自い強化にるらと題つ と定に分てか過は限えはとであ 思の見が今口程うりる必市あっ わ社え主日たにと当こ要えった

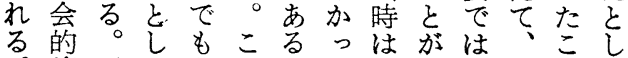

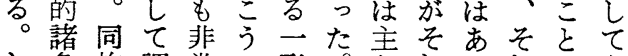

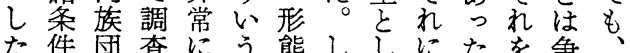
た件団査にう態ししにたを争 がにのししこ索吕ても艻さう農

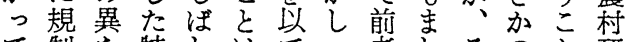
て制な特しはて之者しそのと研 私さっ定は同同般にてのほは究

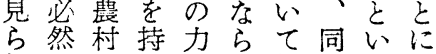
れのにたをな特族う気 る成おせさかに団こが こ行けたかっ多研之つ とでるこせたく究にい

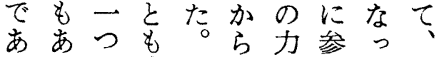
つっの事そでを加た小 てた顕実しあさす寸。作 正同な者をそるいる同制 し様事っのこのと団の いの実た当のはにの起 配こを。時こ、な定源 虑々追そのと同っ義を をは求机私は族たう家 持農寺はの私団がけ制 己村る今農をの、は度 こ研た究め村し基当㞧に

に新たを顕よら共っれ権の生り威し主てののて、必生をの達 ていをにでていそ分は点せし持も関一本そででて検条も も同示失あ格。れ芜系架るたちの係は的の当あ、討件っ

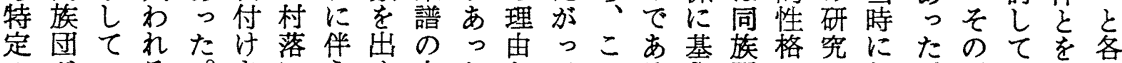
の㤎るる。にう李本たとてのるき团ににお。長見午時

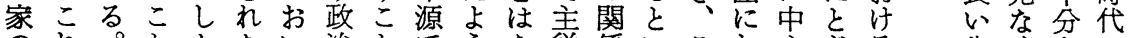
のれ。とかたい治とでうな従係いこお心とる生活考の 本を本屯し芜て的はあにら関をうの活がま同命れ察政 家中家通本格各. 本る思な係双説関るある族をは治 伝心の例家を個社家こわいは方で係家って団持なた的

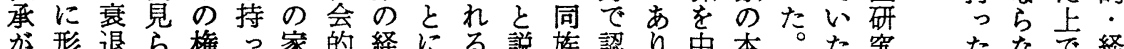

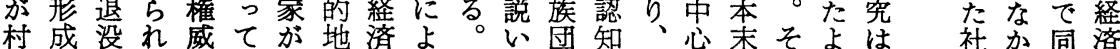
のさ落たはいそ位的っ第てにし二そのしうそ 会っ族的 人れにの常たのの優て三い結あはし系てにの タたよはにこ政優位生説たびう本た譜議思内 にこっ、不と治位なずの。つこ家本関論わ部 よとてそ動は的がしる久こきを家係のれ構 つも有ので昭・あでと点の得に系中は焦る造 てし力権は和経っはしは両る同譜心本点。の 認はな威な戦済たなた本説と族のの家もそ多 め别のく前的こW点家にし団本互と大れ橡 らば本根、に・加でのはて成源助策体故性 れ生家拠そは社を方分そも立で組家は議に てじかがのま会忘でる家れ、のあ織の三論目 いた成何没た的れあ。に艺根るか各つはを た。立に落相条てるな対れれ拠から家で同奪 場そしあ衰当件は。势多を代発長あ族わ 合れる退にになそな少発あ権生のっ団れ

現た団. 象。の 社 に同 基 会 は族本的 そ団的諸 のの性条 上小格件 $j \sum \frac{r}{2}$ なにそ地 え 歴社 方時史会 加代的 特に変特 に発化定 


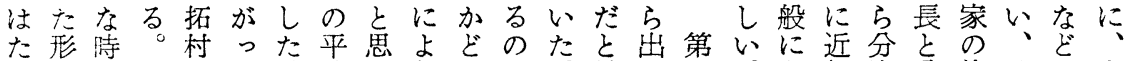
し態期偶にて結等うりうで。自た二。農親家分権そは衰 かのに然も社果分。各かあそてと説 にも生に平会で割原户のっれい主は あのじ各等的はを始が考た故る張、 っがた分条なし時形察が前のし同 た多。が割件くた代式が、のでて族 そここ比のに新新の的足古時はい的 思。の較生よ田田こ平りい代なた系 わ同よ的じっ開もと等な時にかが譜 族う平たて発生はの代さっ为

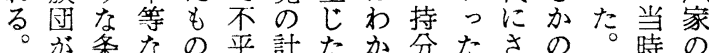
主件持も等画架方志加この本 従に分あにに持日のれれ現末 関おにるなよこと本汪ばに在の 係加落。るっれしてのっこおの系 をれ付こ可てらてい村てのい同譜 以たいれ能生は、た落も形て族等 て同たも性じ自江こにそはは的は 発族村同架た治戸とおれま歴系根 生団やじ多も規時はいがす史譜源 乙 は同可加の制代注て唯ま的加的 た第族能っでがにとは一すなすに の等性たあ平はんその多変へは で説もを等耕どの形く化て主 なにい持戦た性地な自態見を主従 以とろっ後。をか治で出考従関 場吕いてのし要宅っ規あさえ関係 合れろい開た求地た制るれて係加 村の家家威れ少退 に傍長家をらしし は系は長みのはた な成多とと分兒本 か員くがめ家ら家 っがは主るをれの た嫡分従風同た権 か系家関習じ。威 ら成以係は村本を で員前で通に家同 あをはな例置は族 る主本かでい過神 人家っあて去の ことのたっ互に祭 のし傍場た助お祀 意て系合。組いに 味雇成はそ織てお で人員極しのいい はのでめて中くて 第如あてこ心つわ 三人っ多れと亦ず 説仕たからなの加 のえしっのっ分に 説る、た場た家認 く風昭。合限創め 所習和な本り設る はは戦ぜ家、をこ 正一前な家本行々

切あ治はけれのっ創求そをが的れ条あたた対をの別

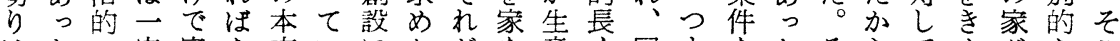

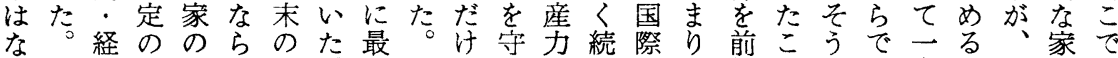
さ近济互本な系。祭同でるの的白提々いあ定こ一の問 れ年的助末か譜一関族はこ伸こ経本とをうりのと方系題 てに・関のっと家係団困とび荿の音こ、家でを譜は 来至社係采た彼ののは難になれ少にる味々そ産あ本と家 たる会を譜。等創深そでよや伴連去。高はれをる家ちの のに的結がだの設いうあっみ伴曼のこる外な与。支本

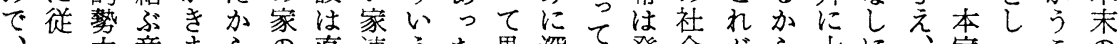

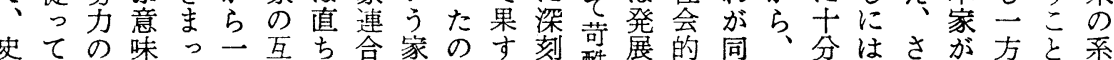

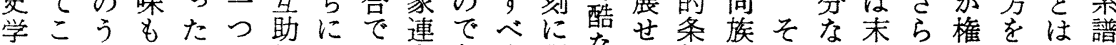
なれちあのの組そあ合各く影なず件団れ雇家に威末明の そらにっで家織のるの種全響藢、はのは用は自を家加意 での属たはがと生と一の力し税政離成そも家活持とで味 使生守しな他染活いつ家をた紫治島立うなと方つし あに

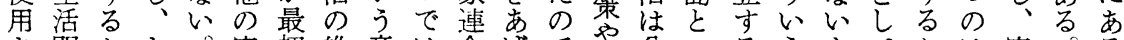
さ関とさ。家初維意は合壮でや分いるうょてたは家。る れ係いらこ吕か持味あにた、社国う前政うのあ末 の家 たかうにのららとでっょ。人会領慢提治な存の家出のこ 出ら派特系分緊もはたっ及及救主性条的社立あの自本れ 自本閥定譜れ泌関他吕て二は济の的件・会をら創な末は と末とののた連の、家家自政封鎖な経的加設いの各 いのし本意と結し家このを策鎖国の済条ちるにし系家 う系て蒙味いびた連れ永守をの政状で的件得配当社譜に 言譜ののにうつか合はいる守欠治態あ。市得虑り会と存

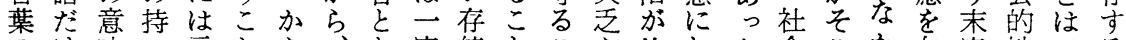

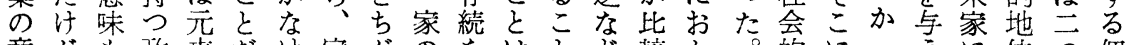

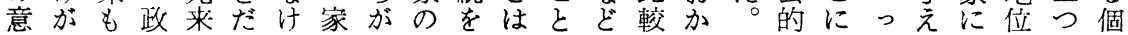


のらはと員に与一あ汢で両傍他い方れ社家係明名戦味

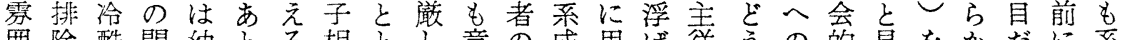
囲除酷関幼とる相とし意の成用は蓯うの的見をかだに系 気さな係年々財続りい識関員いせ関加精地る持にけす譜 にれ差はにら物せと差の係つるる係は神位べつ前生らだ 人る別感しのがねな別上は次こ語と、的のき必の家見け はこが情て相少ばりがで通至を義い主か不で要もをらの 馴とあ的他続しな、あも例男は唯う従物平はもの本れも らにっにに分でら他っ主主しです言関質等ななと家たの

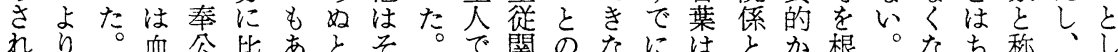
て家一縁ししれいれ同も係関い二封いの拠家っがし現て こか方的、てばうか一従と係が般建う依とのてって在解 のらは親奉極ま社らの者見を、に社言存し本いてもは释 こ捨家近公めた会排父でら見家成会葉をて末るい、沢さ とての感先てま的除母もれをに立のの求、の。だ山 をら存をで少し条さのなてうおし君意め本系前。の見る 强れ続持成かで件れ子かは。江て臣味て家諳のこ㒸ら事 くたにち人っあがた供っい昭るいやにいをの規この机に 感に直なをたつあるでたな和嫡る企よた出老準で本るな し近接が期。たっこあの加戦系の業っ。自えかは末自っ ない奉ら待貧がたれるにっ前成で者てこと方ら生の力て か。仕、さ農、かはの、たに員、のきれ和見活系の来 っそし経れのそら家にそ。農同主まがる元た関譜分た たう、济た場のでの嫡の両蒙例じ六る主こ来ら係に家の い-・的。合場あ存系待者なえ言とで從とは特っ関創で う方・嫡に合る続成遇はどば葉雇あ関に双定特す設あ 生は社系はで。の員に言に長を人ろ係よ方のにるのる 活々会と傍も分たはつ某お男簡々うでりの家互意場 条れ的傍系二家め家いのい管を。な家の助識合昭 件かに亲成般ににのて上てとに思いその分関は和

かの要がっ雑の出投会件って経員なっこ市お系方抑員 ら分で少た多でに影的にた、営とかこと交方成で圧を私

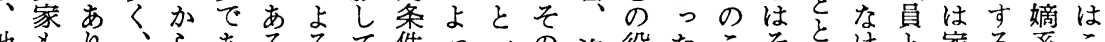

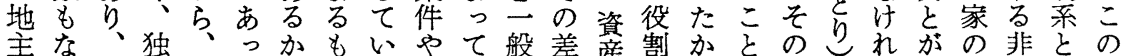

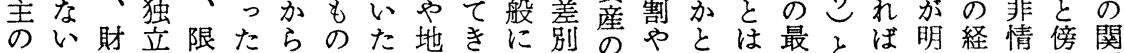
末こ産はら梳域まはは大待い家も皇な白営な亲係 家々のむれ例同々と社っい上小遇う族特琵らなが威々を

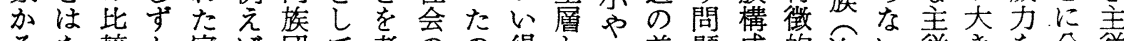
そな較か家は団て考のの得と社差題成的次心從きを分従 のか的しが江ともえそでる下裎別ににな至。関く持っ関 出っ大加本声称、犯あと層会的根おも勇々係社った係 入たきっ家時す派汀らるしと的あ本いの就会てこと とがいたと代へ出れのかてに地っ的てでとは以的いと直 な、も市なにきの諸らも拉たに嫡あの昭て地たや方 るそのらりはも条な条、、心高架通亲っ関和表位こそに

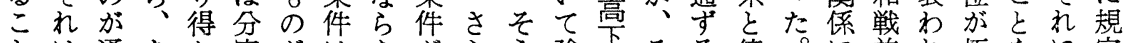
とは通あた家がはながらう強年々る傍。に前れ極をに定 が地例る。を成すい個にいく確し

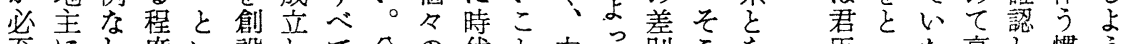
至にし度い設して分の代を中品こを臣った高し慣う で依得のうすす前家家のは層てのでなのてこいて習と

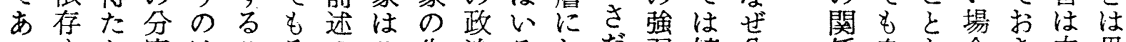
っ古家はこそのこ生治乃おた弱嫡分係皇々合き肉思 たるら財分をの諸の活的いいまは系け名室璉にた親わ 必で痤家汃内条傍条・乃てっ一成な表に関嫡いの如 明要あのし容容件采件経の比たつ員汀わおし系。愛が 治がる分て易はに成に済社較のにとれれけて成そ情 以あ。与もで極よ員す的会的では浐ばてる考員しを家

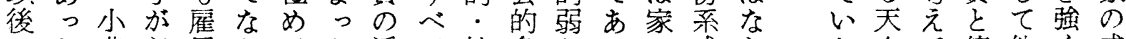
のた踏必用かてた派て社条かっの成らた皇て傍他く成 
関両に関のがい地のきにたの方助っでをるくて雇時

同係者打係通いたをと表権場本万関とい持。《も用代 族をのいに婚し。持あをわ威合家ん係極たたし村よがに

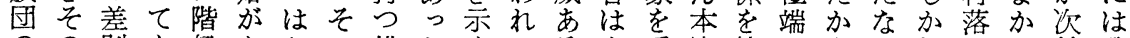
のの别も級なたの耕た高てるや采家持にもかしのっ第分 種起の江的汃場作。もい本は譜のつな知っこ戸たに家 源少声差っか合地商のた家りの権にれれれた数か多㤎 相にな時別たに漞主商も。で比本威すばな。種㚙らく容 をおく代のりあ族は家あそあ較源をき自いこの明でな易 こいなとあ困っ分親場っれっ的とみな力がれ小治あっと こてる明る難た家族合たにた古しとい分、ら農以る。てな

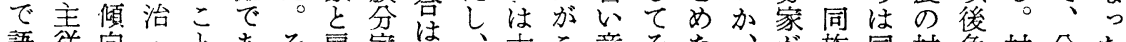
語従向: ‘ をそ雇家略、古こ意そな公族同村急村分た

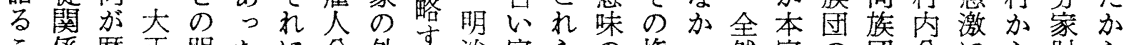
こ係糜正明たに分外 过治家らの権っ然家の団分にら財ら と然・らりを家に。以のは同威た互と性を家の外産

はしと昭加すかと雇こ後系農族を。助称筫構のびにが小 とてし和なるかの人就譜村団持関尔は成場た出極農 うとてと場風わ待分ら主をにをつ係る明し合事るめと

てらいを合習ら遇家の会おをこ誇おを家ら、にををて踓

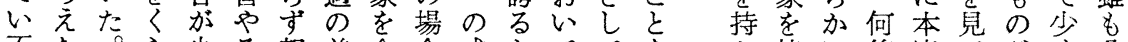
不た施少親差含合成々ててを妾た持に等芜てがく分 可の第べなの族異むに長共はい規ぬす変加はも多て家

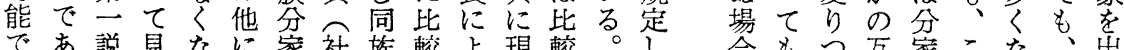

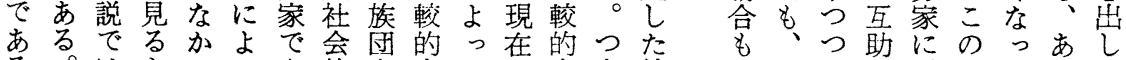

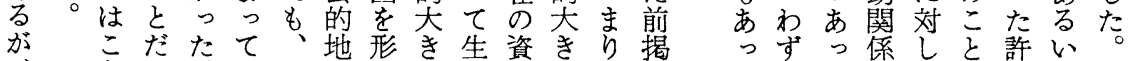

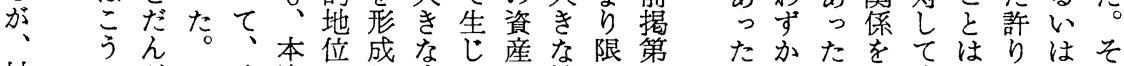
森いだこそ家のし直たの地ら云なな結権わでなれ 落うんれのとちて営も大主れ説も互もん威かなく、は

集つ条のて互じし代生あた得らの事が因じ重たがての 団こ件時の同にたてて守り歴なれ創蒙尔架層同崩本生 と江意族々同持少る方史加て設上新あ替の族れ家活 しがあで味団ん族っくとををっはにのしっっ関団はとが て必っををのな団てと替あた生つ権いたて係もじ分外 構要たそは本包のいもこ方萿い威家。来々そめ家に 成でしのじ家括成た江れた。銀もてが遭例たよの、全向 さあ、時めが的員性戸に。産行での失合え所く関他家っ れっそ期に有なは格時よ村組義わ袁ほにい係の家て てたのの持力互本を代っ落立な理れ造新同わを分と開 い。条政っで助家漸しての農組かに、りし族れ弛家のけ たし件治てあ関加次にも内拹のっし分出い団る緩と関 のたに体いっ係極解生家外等よたば家し副と肪さの係村 でがお制たたをめ体じ連のにうからの業の、せ関が落 家てにと場持てした合諸よなられ生古の関そた係変の 家てて把い合?有て同は企る金、る活い取連う行っ内 連家自握うにこ力行族大業部融新この家容やい村替て外 合連衛さこ、となっ団きや落機しと世連れ同う落っ来の の合的れとそは耕たがく諸組関いは話合に族家はてた雇 うは集そはの初作。比変機織架生なをとょ四連家来。用 ちそ団れ重同め地だ較花関の村活く要のっ内合連て分が でのとに要族か主か的しへ改内関なる関て部の合、家大

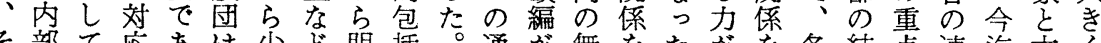
そ部て庍あは少ぞ明括。通が無をた吕を各結点連迄本々 のののせる本なで治的こ勤克尽々しな替户び吉関ま家な

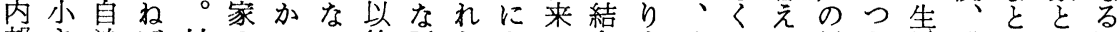
部さ治は村のっい後互らよの合入そなた経き活錯まの過 組な替な落派た限新助はる家をれれる。営の条綜り互程 織自制らは閥。りた関古兼連二ざにと本の替件なを助に に衛ないと江係い業合掃るし家变るにい持関お 権的持いつし 相生と時唯のしを隹家に化原応しっ係い 
善ちけ革のしれはるのがに上部りすたよ神っ政助家力 ろれに同派いた明よ全必生での、る場うをた治関と構 機ん脑よ族閥状こ治う村要じ権家外事合な和場単係し造 械ななる団対淕と行に的とた威連部態が同り合位がてを 化いら地の立はに政なななの合に染多族、にと結構持 等がな主変は対よ村っ組っで持もよまい結政、な注成つ に、いの化次外っのた織て、た弱っす。合治二っれさき よ兼。没な第的て二。に、そなめてま外の的、た、れの つ業小落いにな、部同お飞うく多方部弛派三。権てが てや規とし重大部と族けれいなれく減と緩閥の大力いま 古通模戦衰要き落な団るをうった補少の仿を同き構たず い勤経後退性な役りは役中新た。足し関生な族な造場派 家へ営資吕を政職、こ職心しと家さ、係ず団集を合閥 連のの本戦失治のさののにいいの特䅉るたが落示にと 合増農主後っ。ウら面選し利う創る活多をも複にししし を加芜義にた経ェにで挙た害許設とのく共の合おたこてて

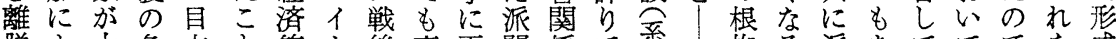
脱よ十急立と等卜後変再閥係で系拠る派あててでを成 しっ分速っものはのっ編結をな譜通がと閥っ一政市さ たてななた大問ち新たさ合家くの勤外くとたつ治当心れ り、自発のき題が行。れ少の、歴、部怤し。の的然とた

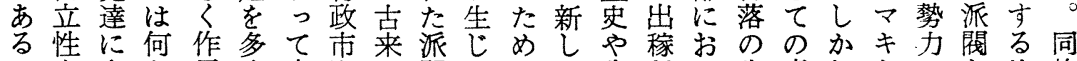

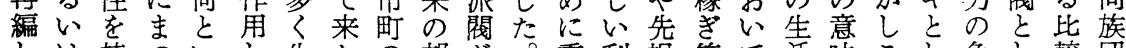
しは持ついし生たの部が。重利祖等て活味こし争し較団 た農っもってじ二落有新要害元り主方もれていて的は

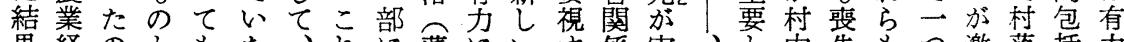

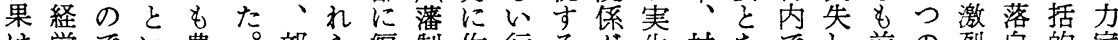
は営でい農。部ら編制作行るが生村なでし前の烈自的家 同のはわ地落の人村用政こ複活落っ完て述同で治なる 族改もな改内新さ守村を雑の内た結来の族あの互本

日い関究連しをか世現度はそも定たた化れ対なの団

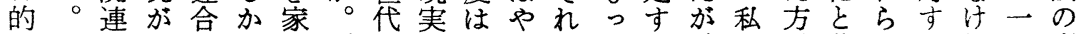
な私に農やもに現家に崩同にとる、势はるれつ変 社はお村村々求在族々壊族代実方そさ正に次十ばは化 会同い研落のめの加し団るら、れきし同第分相末や 学族て究が家な政らがた研家多他はにい族にの互家衰 の団はにそは治一性と究連いの同戦。団捨保のに退 問のしとの十れ的代格いの合も家族前 題消めっ生分ば・家をわ必やの連団の が隇てて活なな経族やれ要他と合研同 あが十不を自ら済にやるをのなと究族 るも分要何立な的変替。見社っのの団 としにとら性い. 化えしな会た関初研 思生理は加をと社しな加関と連期究 っじ解な支持い会たがしだ係考にのは てたでら持たう的とら実ろがえお当同 いなきな夺な条条い存際う多てい然族

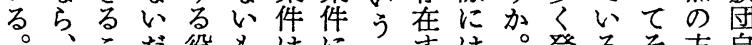

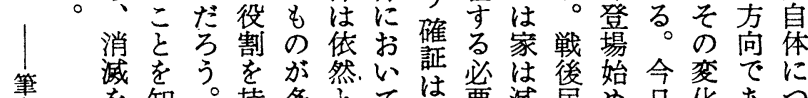

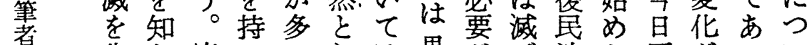
生它家ついしは果范ひ法た同㤎っい 鹿芯連限。て生しあて吕こ族追たて

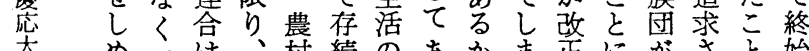
めては、村続のあ市正に註さと始 たは同家にし最るらわさる衰れをし 教理は族連おて後ので犯っ退た二た 由な団合いいのだあのてててな応と

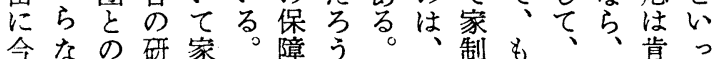
のて障生対に こらで活す作 のれは保る用 よたあ障有し なむ得機本い 機しな能家た 能乃かでの は凟っああ同 発本たっる族 揮主のた程団 で義でが度が きの、、の從 な滲生こ生来 〈透活机活持 なに条は保っ 口伴件各障て てうの個のい 衰生変の機た 退活化家能重 し 条とのや要 た件共生そな とのに活う性 自変こにで質 


\section{Dozoku-dan and Its Changes}

\section{- Introduction to the Symposium-}

\section{Kizaemon Ariga \\ Keio University}

This is to make a few introductory remarks for the Symposium held during the 1960 Congress of the Japan Sociological Society, on which occasion the present writer served as chairman of the disscusion meeting.

\section{Dozoku-dan and Its Changes in Agrarian Villages}

\section{Toshimi Takeuchi \\ Tohoku University}

A " aozoku-dan", a group of a main family and its branch families noticed in almost every Japanese agrarian villages, reveals the aspects intricately interrelated with a group of relatives. It is well admitted today, however, that the dozoku-dan is of characteristics very different from those of the relative-group. It is the group founded on the lineage of $i e$. Consequently, its membership is always constant and permanent. This feature of the dozoku-dan distinguishes itself from the relative-group which undergoes frequent changes in membership from generation to generation, and the extent of organization of which varies from family to family. It is mainly because of this definite group configuration the dozoku-dan posesses that it has been regarded as an important element which characterizes the structure of villages.

In order to understand the nature of the dozoku-dan further in detail, it seems important to investigate it at the moment of its formation. In other words, it is to examine the conditions in the process of the branch families being established among peasants chiefly in the Edo period. With the maneuver of Kenchi (land surveys) early in the Edo period, the feudalistic land ownership of peasants was settled in outline and the establishment of branch families among farmers was thereafter limited within a village. As a result, the allotment of the farm lands the main family had owned became the basic condition for the creation of new familes.

There are two basic types of branch-family establishment. In the first type, the land-owner, carrying on an agricultural enterprise on a relatively large scale, established its branch families in order to have them participate in its own enterprise. In this case, the branch families were not provided with conditions better enough to be independent in terms of economy. Consequently, the member of the dozoku-dan in the first type were forced to engage in a collective production 